\title{
Relationships between functional herd life and conformation traits in the South African Jersey breed
}

\author{
J. du Toit ${ }^{1,2 \#}$, J.B. van Wyk ${ }^{2}$ \& A. Maiwashe ${ }^{3}$ \\ ${ }^{1}$ Agricultural Research Council, Animal Production Institute, Private Bag X5013, Stellenbosch, 7599, South Africa \\ ${ }^{2}$ Department of Animal, Wildlife and Grassland Sciences, University of the Free State, P. O. Box 339, Bloemfontein, \\ 9300, South Africa \\ ${ }^{3}$ Agricultural Research Council, Animal Production Institute, Private Bag X2, Irene, 0062, South Africa
}

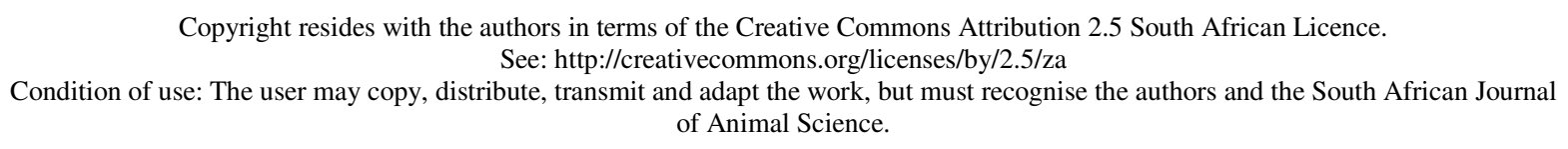

\begin{abstract}
The genetic relationship between conformation traits and functional herd life of the South African Jersey population was investigated. Data on conformation traits $(n=46238)$ and functional herd life $(n=$ 90 530) on registered South African Jersey cows calving between 1989 and 2008 were obtained from the Integrated Registration and Genetic Information System. Conformation traits were scored using a subjective linear scoring system ranging from 1 to 9, except for foot angle, with a maximum score of 8 . Conformation traits included stature, chest width, body depth, dairy strength, rump angle, thurl width, rear leg side view, foot angle, fore udder attachment, rear udder height, rear udder width, udder support, udder depth, front teat placement, rear teat placement and front teat length. Genetic correlations between conformation traits and functional herd life were estimated by a series of bivariate analyses. Significant moderate to strong positive genetic correlations between most udder traits and functional herd life $(0.23$ to 0.63$)$ were estimated. The most important udder traits related to functional herd life were fore udder attachment, rear udder height and udder depth. Most of the body structure traits had a low to moderate negative correlation with functional herd life (-0.04 to -0.27). However, rump angle and foot angle were estimated to have a moderate positive genetic correlation with functional herd life. The genetic relationships between functional herd life and conformation traits in the South African Jersey breed indicate that conformation traits could be used to enhance the accuracy of genetic evaluation for functional herd life. It is therefore recommended that current national genetic evaluation for functional herd life in the South African Jersey breed should include conformation traits.
\end{abstract}

Keywords: Functional herd life, genetic correlations, linear traits

\#Corresponding author: dtoitj@arc.agric.za

\section{Introduction}

Functional herd life in dairy cattle is of economic importance because longer herd life is associated with lower heifer replacement costs and a higher proportion of more productive mature cows in the herd. Therefore, functional herd life is an integral part of the breeding objective for dairy cattle. Research has shown that genetic variations exist for functional herd life to allow for genetic improvement through selection (Vukasinovic et al., 2001; Cruickshank et al., 2002; Tsuruta et al., 2005). The challenge of using direct measures of functional herd life in the genetic improvement programme is that this trait can be observed only at the end of productive life. For maximum genetic progress, the genetic merit of animals must be evaluated on information that is available early in their lifetime. Thus, direct selection for increased functional herd life may take too long. It is therefore important to identify and emphasize traits associated with herd life that are expressed early in life to allow breeders to select for profitable and functional cows. 
Low to moderate genetic relationships between various conformation traits and functional (milkcorrected) herd life were reported in the literature. The highest genetic relationships were generally found for udder attachment, udder depth, teats, and angularity of rear legs (Vukasinovic et al., 2002; Strapák et al., 2005; Bouška et al., 2006; Zavadilová et al., 2009). In a study on Quebec Holsteins, Schneider et al. (2003) found that udder and stature had the strongest relationship with functional herd life, compared with other structural body traits. Furthermore, Bouška et al. (2006) reported positive relationships between udder traits in particular and herd life for Czech Fleckvieh cows. Similarly, Caraviello et al. (2003) found that udder depth was by far the most important type trait with respect to herd life, followed by fore udder, front teat placement and udder support in US Jersey cows. In a study on US Holsteins, Tsuruta et al. (2005) found that more capacious and better attached udders, shorter teats, smaller body size, straighter legs, steeper foot angle and higher overall conformation scores were consistently related to increased herd life.

It is evident that desirable conformation traits can positively influence the functional herd life of cows and thus the economic efficiency of the herd. Type classification data have been recorded on registered South African Jersey cows since 1989, and their use as an indirect predictor for herd life may be very cost effective. Besides being measurable early in life, type traits are more heritable than herd life, which can be influenced heavily by management and environmental factors (Caraviello et al., 2003). Genetic evaluation for herd life, including correlated conformation traits, may be more accurate than evaluations based on survival information alone (Boldman et al., 1992). The main objective of this study was to estimate the genetic relationships between functional herd life and conformation traits in the South African Jersey breed.

\section{Materials and Methods}

Data on conformation traits on registered South African Jersey cows that had calved between 1989 and 2008 were obtained from the South African national database, the Integrated Registration and Genetic Information System (INTERGIS). These cows participated in the South African National Milk Recording and Improvement Scheme. For convenience, the conformation traits were grouped into body structure and udder traits (Table 1). Body structure traits included stature (wither height), chest width, body depth, dairy strength (a composite trait consisting of chest width, body depth and angularity), rump angle, thurl width, rear leg side view and foot angle. Udder traits included fore udder attachment, rear udder height, rear udder width, udder support (udder cleft), udder depth, front teat placement, rear teat placement and front teat length. These traits were scored only once, preferably on cows in their first lactation. After editing, $80 \%$ of the records were from cows scored in their first lactation and $20 \%$ in their second lactation. A subjective linear scoring system ranging from 1 to 9 was used, except for foot angle, with a maximum score of 8 .

Data editing for conformation traits was carried out according to the standard editing criteria used in the South African National Genetic Evaluation Programme for the Jersey breed. Briefly, data from cows younger than 17 months or older than 36 months at first calving, and younger than 29 months and older than 53 months at second calving were excluded from the analyses. Cows younger than 17 months or older than 46 months when scored at first parity, and those younger than 29 months and older than 63 months when scored in the second parity were also excluded from the analyses. Cows with days in milk that were fewer than 5 and more than 300 were also excluded from the analyses. Contemporary groups with at least five animals that are progeny of at least two sires were considered. A contemporary group was defined as a concatenation of herd-year-season-classification code and parity. Descriptive statistics of the final data set are provided in Table 2 .

The following data were used in the analyses of herd life. A total of 4189393 test-day records were obtained from INTERGIS. Functional herd life was defined as a series of binary traits indicating survival through the first, second and third lactation, adjusted for production. Similar data had been used previously in estimating genetic parameters for functional herd life (Du Toit et al., 2009). The editing criteria employed in the national evaluation for milk production traits for the Jersey breed were used. The following records were excluded from the analyses of functional herd life: (1) test-day milk yield $<1 \mathrm{~kg}$ or $>70 \mathrm{~kg}$, fat yield $<2 \%$ or $>9 \%$, and protein yield $<2 \%$ or $>6 \%$; (2) first test exceeding 75 days; (3) at least one interval between test dates exceeding 100 days; and (4) records with more than one test date interval between 60 and 100 days. Further editing included these amendations: (1) first lactation records terminated before 01 January 1989 were excluded because records prior to this date comprised only completed lactations without test-day records, (2) lactations with fewer than 5 days and more than 305 days in milk were excluded, (3) records with incorrect herd code, yields equal to zero, and records out of specified age range were excluded; the 
allowable age ranges were 17 to 36,29 to 53, and 41 to 67 months for first, second and third calving, respectively, (4) records with unknown registration status were excluded, and (5) a first parity record was required for all cows. Furthermore, records from cows with unknown sires were excluded. Cows born after 2004 were excluded owing to limited number of records.

Table 1 Classification system for conformation traits in the South African Jersey breed

\begin{tabular}{lcccc}
\hline Score & 1 & 5 & 9 & Ideal score \\
\hline Body structure & & & & \\
Stature & short & intermediate & tall & 6 \\
Chest width & narrow & intermediate & wide & 6 \\
Body depth & shallow & deep & very deep & 6 \\
Dairy strength & frail & intermediate & strong & 8 \\
Rump angle & high pins & level & extreme slope & 6 \\
Thurl width & narrow & intermediate & wide & 8 \\
Rear leg side view & straight & intermediate & sickled & 6 \\
Foot angle & very low & intermediate & very steep & 7 \\
Udder traits & & & & \\
Fore udder attachment & weak & intermediate & strong & 8 \\
Rear udder height & low & intermediate & high & 8 \\
Rear udder width & narrow & intermediate & wide & 7 \\
Udder support & indistinct & deep & very deep & 6 \\
Udder depth & deep & intermediate & shallow & 7 \\
Front teat placement & wide & Centre & narrow & 7 \\
Rear teat placement & wide & centre & narrow & 5 \\
Front teat length & short & intermediate & long & 5 \\
\hline
\end{tabular}

A series of bivariate analyses, including one conformation trait and one functional herd life trait, were carried out to estimate genetic correlations between functional herd life and conformation traits. The matrix representation of the model fitted is as follows:

$$
\mathbf{y}=\mathbf{X b}+\mathbf{Z u}+\mathbf{e}
$$

Where $\mathbf{y}$ is a vector of records, $\mathbf{b}$ a vector of fixed effects, $\mathbf{u}$ is a vector of random direct additive genetic effects and $\mathbf{e}$ is a vector of random residual effects. The fixed effects considered for conformation traits were contemporary group, age at classification (fitted as linear and quadratic), and days in milk (fitted as linear and quadratic). The fixed effects for functional herd life were herd-year, registry status $\mathrm{x}$ herd size change $\mathrm{x}$ season of calving (rhs), age at calving (fitted as linear and quadratic), protein within rhs, protein and fat yield deviations (fitted as linear, quadratic and cubic). $\mathbf{X}$ and $\mathbf{Z}$ are incidence matrices relating to fixed and random effects with the observations. (Co)variance components were estimated using VCE6 (Groeneveld $e t$ al., 2010). Estimates of genetic correlations were considered significant if the absolute value was greater than twice the standard error of the estimate.

\section{Results and Discussion}

Table 2 presents the descriptive statistics and trait abbreviation for functional herd life and conformation traits. The mean phenotypic scores for stature and chest width were 5.4 and 5.6, respectively, and close to the ideal score of 6 . Mean score for body depth was approximately 7 (ideal score 6) and 6.6 
(ideal score 8) for dairy strength, which indicate a tendency towards a deeper, but more frail cow. In terms of the structural body traits, rump angle, and rear leg side view, the scores were in the range of the ideal scores. The results on the structural body traits indicate, on average, a narrower, lower foot angled, and hocked rear leg cow. For udder traits, fore udder attachment and rear udder height were approximately 1.5 points lower than the ideal score of 8. A similar result was observed for rear udder width. Front teat placement was more than 2 points below the ideal score of 7 , indicating on average a wider, more undesirable front teat placement. Scores for udder depth and udder cleft were close to the ideal scores of 7 and 6 , respectively. Scores for rear teat placement and teat length were also close to the intermediate scores of 5.

Table 2 Descriptive statistics and trait abbreviations for functional herd life and conformation traits in the South African Jersey breed

\begin{tabular}{|c|c|c|c|c|c|c|c|}
\hline Traits & Abbreviation & Number & Mean & $\mathrm{SD}$ & $\mathrm{CV}(\%)$ & Min & Max \\
\hline \multicolumn{8}{|l|}{ Functional herd life } \\
\hline First lactation & FHL1 & 90530 & 0.72 & 0.45 & 62 & 0 & 1 \\
\hline Second lactation & FHL2 & 56854 & 0.72 & 0.45 & 63 & 0 & 1 \\
\hline Third lactation & FHL3 & 33885 & 0.68 & 0.47 & 70 & 0 & 1 \\
\hline \multicolumn{8}{|l|}{ Body structure } \\
\hline Stature & WH & 46237 & 5.40 & 0.82 & 15 & 1 & 9 \\
\hline Chest width & $\mathrm{CW}$ & 22484 & 5.60 & 0.69 & 12 & 1 & 9 \\
\hline Body depth & $\mathrm{BD}$ & 22484 & 7.03 & 0.78 & 11 & 1 & 9 \\
\hline Dairy strength & DS & 46238 & 6.63 & 0.80 & 12 & 1 & 9 \\
\hline Rump angle & RA & 46238 & 5.54 & 0.65 & 12 & 1 & 9 \\
\hline Thurl width & TW & 46238 & 5.49 & 0.73 & 13 & 1 & 9 \\
\hline Rear leg side view & RLS & 46238 & 5.64 & 0.59 & 10 & 1 & 9 \\
\hline Foot angle & FA & 46238 & 4.92 & 0.71 & 14 & 1 & 8 \\
\hline \multicolumn{8}{|l|}{ Udder trait } \\
\hline Fore udder attachment & FUA & 46238 & 6.55 & 0.90 & 14 & 1 & 9 \\
\hline Rear udder height & RUH & 46238 & 6.48 & 0.77 & 12 & 1 & 9 \\
\hline Rear udder width & RUW & 46238 & 5.65 & 1.09 & 19 & 1 & 9 \\
\hline Udder support & $\mathrm{UC}$ & 46238 & 6.20 & 0.84 & 13 & 1 & 9 \\
\hline Udder depth & UD & 46238 & 6.94 & 0.69 & 10 & 1 & 9 \\
\hline Front teat placement & FTP & 46238 & 4.69 & 0.85 & 18 & 1 & 9 \\
\hline Rear teat placement & RTP & 14061 & 5.34 & 0.95 & 18 & 1 & 9 \\
\hline Front teat length & FTL & 22482 & 4.32 & 0.98 & 23 & 1 & 9 \\
\hline
\end{tabular}

$\mathrm{CV}=$ coefficient of variation; $\mathrm{SD}=$ standard deviation; Min = minimum; Max = maximum.

Heritability estimates for all the traits are presented in Table 3. Heritabilities for functional herd life were low and consistent with those reported by Du Toit (2009). Estimates of heritability for conformation were comparatively higher than those for functional herd life. Theron \& Mostert (2004) used a subset of the data considered in the current study, and reported estimates of heritability for conformation traits that were similar to those found in the current study. In general, heritabilities found in the current study were consistent with literature estimates (e.g. Van Niekerk et al., 2000).

Genetic correlations between functional herd life and conformation traits are presented in Table 3. Correlations between functional herd life and body structure traits were variable. In general, body structure traits had a low to moderate negative correlation with functional herd life $(-0.04$ to -0.27$)$, except for stature, 
where the genetic correlation was positive (0.15). Samoré et al. (2010), in a study on Italian Brown Swiss, also found low to moderate negative genetic correlations between body structure traits and functional herd life (-0.07 to -0.22$)$. However, only body depth, dairy strength, rump angle, thurl width and rear leg side view were significantly correlated with functional herd life in the current study. The small genetic correlation between rear leg side view and functional herd life observed in the current study is consistent with the results by Vollema \& Groen (1997), who reported a negative genetic correlation between rear leg side view and functional herd life (-0.17). Cassandro et al. (1999) reported a negative genetic correlation of -0.29 between rear leg side view and functional herd life, which is slightly higher than in the current study. Cruickshank et al. (2002) and Tsuruta et al. (2005) reported a somewhat smaller genetic correlation between rear leg side view and functional herd life than in the current study. In the current study, rear leg side view is a trait with an intermediate optimum. Our results indicate that sickled cows will have a shorter functional herd life compared with straight leg cows. This is not consistent with the fact that rear leg side view is an intermediate optimum trait. In fact, Buenger et al. (2001) observed that sickled rear legs and extremely straight legs led to a lower functional length of productive life, a result that is in accordance with the curvilinear biological relationship between the two traits and indicates that the selected statistical approach may not be the most appropriate. Therefore, the negative genetic correlation that is observed in the current study should be interpreted cautiously.

Table 3 Heritabilities $\left(\mathrm{h}^{2}\right)$ and genetic correlations $\left(\mathrm{r}_{\mathrm{g}}\right)$ for and between functional herd life and conformation traits in the South African Jersey breed

\begin{tabular}{|c|c|c|c|c|}
\hline \multirow{2}{*}{ Item } & \multirow{2}{*}{$\mathrm{h}^{2}$} & \multicolumn{3}{|c|}{$r_{g}$} \\
\hline & & FHL1 & FHL2 & FHL3 \\
\hline \multicolumn{5}{|l|}{ Body structure } \\
\hline Stature & $0.20 \pm 0.010$ & $-0.04 \pm 0.07$ & $-0.05 \pm 0.16$ & $0.15 \pm 0.13$ \\
\hline Chest width & $0.08 \pm 0.015$ & $-0.04 \pm 0.12$ & $-0.14 \pm 0.23$ & $-0.15 \pm 0.21$ \\
\hline Body depth & $0.14 \pm 0.018$ & $-0.19 \pm 0.10$ & $-0.25 \pm 0.21$ & $-0.27 \pm 0.10$ \\
\hline Dairy strength & $0.10 \pm 0.008$ & $-0.01 \pm 0.09$ & $0.31 \pm 0.17$ & $0.29 \pm 0.15$ \\
\hline Rump angle & $0.17 \pm 0.012$ & $-0.19 \pm 0.08$ & $0.22 \pm 0.15$ & $0.15 \pm 0.14$ \\
\hline Thurl width & $0.07 \pm 0.009$ & $0.14 \pm 0.10$ & $-0.03 \pm 0.13$ & $-0.01 \pm 0.17$ \\
\hline Rear leg side view & $0.04 \pm 0.007$ & $-0.16 \pm 0.06$ & $-0.43 \pm 0.21$ & $-0.17 \pm 0.17$ \\
\hline Foot angle & $0.10 \pm 0.009$ & $0.16 \pm 0.09$ & $0.35 \pm 0.19$ & $0.33 \pm 0.15$ \\
\hline \multicolumn{5}{|l|}{ Udder traits } \\
\hline Fore udder attachment & $0.09 \pm 0.010$ & $0.23 \pm 0.10$ & $0.63 \pm 0.14$ & $0.33 \pm 0.15$ \\
\hline Rear udder height & $0.13 \pm 0.011$ & $0.28 \pm 0.09$ & $0.54 \pm 0.13$ & $0.37 \pm 0.14$ \\
\hline Rear udder width & $0.14 \pm 0.011$ & $0.14 \pm 0.08$ & $0.36 \pm 0.14$ & $0.06 \pm 0.13$ \\
\hline Udder support & $0.09 \pm 0.009$ & $0.17 \pm 0.09$ & $0.36 \pm 0.16$ & $0.26 \pm 0.15$ \\
\hline Udder depth & $0.16 \pm 0.011$ & $0.10 \pm 0.08$ & $0.49 \pm 0.18$ & $0.39 \pm 0.15$ \\
\hline Front teat placement & $0.23 \pm 0.011$ & $0.08 \pm 0.06$ & $0.28 \pm 0.13$ & $0.19 \pm 0.12$ \\
\hline Rear teat placement & $0.20 \pm 0.028$ & $-0.03 \pm 0.11$ & $-0.21 \pm 0.25$ & $0.29 \pm 0.18$ \\
\hline Front teat length & $0.27 \pm 0.019$ & $0.10 \pm 0.09$ & $-0.34 \pm 0.17$ & $-0.07 \pm 0.10$ \\
\hline
\end{tabular}

FHL1; FHL2; FHL3= functional herd life for lactation 1, 2 and 3 respectively. Heritabilities and standard errors for FHL1, FHL2 and FHL3 were $0.04 \pm 0.007,0.01 \pm 0.003$ and $0.03 \pm 0.005$ respectively.

A moderate genetic correlation between dairy strength and functional herd life was observed in the current study. This genetic correlation is indicative of a favourable association between the two traits. However, corresponding genetic correlations ranging from -29 to 0.47 were reported in literature (Short \& 
Lawlor, 1992; Weigel et al., 1998; Cruickshank et al., 2002; Zavadilová et al., 2009; Samoré et al., 2010). For example, Cruickshank et al. (2002), in a study on registered US Guernsey cows, reported a moderately negative estimate of genetic correlation between dairy strength with functional herd life (-0.29).

The genetic correlation between body depth and functional herd life in the current study was small and negative (-0.19). Zavadilová et al. (2009) reported a similar negative genetic correlation (-0.16) in a study on Czech Fleckvieh cows. Weigel et al. (1998) and Samoré et al. (2010) found slightly lower genetic correlations of -0.07 and -0.10 , respectively. Tsuruta et al. (2005) found a somewhat higher genetic correlation $(-0.26)$ between body depth and functional herd life. The negative correlation between body depth and functional herd life indicates that cows with high scores for body depth (very deep) will tend to have a lower functional herd life. However, cows with low scores (shallow) will have longer functional herd life. This may present a problem for selection since body depth is known to be an intermediate optimum trait.

Rump angle was negatively correlated (-0.19) with functional herd life 1 in the current study. This genetic correlation was in agreement with the results (-0.11) reported by Cruickshank et al. (2002). However, the genetic correlation between rump angle and functional herd life reported in most of the studies ranged from 0.07 to 0.21 (Jairath et al., 1998; Weigel et al., 1998; Cruickshank et al., 2002; Zavadilová et al., 2009; Samoré et al., 2010).

A moderate positive genetic correlation (0.33) was observed between foot angle and functional herd life 3 in the current study. This positive genetic correlation indicates that foot angle is one of the most important potential indicators of functional herd life. Smaller genetic correlations of 0.04 and 0.15 were reported by Cruickshank et al. (2002) and Tsuruta et al. (2005), respectively.

Significant moderate to high positive genetic correlations between most udder traits and functional herd life ( 0.23 to 0.63$)$ were observed in the current study. Rear teat placement and front teat length were the only two udder traits that were not significant. The genetic correlations were more pronounced in the second lactation for all the udder traits, except for rear teat placement. These genetic correlations indicate that fore udder attachment, rear udder height, rear udder width, udder support, front teat placement and udder depth are the most useful indicators of functional herd life. Consistent with our genetic correlations between udder depth and functional herd life of 0.39 and 0.49 , estimates ranging from 0.28 to 0.43 were reported in the literature (Vollema \& Groen, 1997; Cassandro et al., 1999; Vukasinovic et al., 2002; Samoré et al., 2010). This general consistency across studies of the genetic correlation between udder depth and functional herd life indicates that udder depth is one of the most versatile indicators of functional herd life. Therefore, udder depth should receive higher priority in the genetic evaluation for functional herd life.

The genetic correlation between udder support and functional herd life 2 was 0.36 in the current study. In general, the corresponding estimates reported in the literature were variable, ranging between -0.06 and 0.31 (Cassandro et al., 1999; Cruickshank et al., 2002; Vukasinovic et al., 2002; Tsuruta et al., 2005; Samoré et al., 2010).

Literature estimates for genetic correlation between fore udder attachment and functional herd life ranged from 0.15 to 0.32 (Cassandro et al., 1999; Vukasinovic et al., 2002; Tsuruta et al., 2005). While our corresponding estimate overlaps with the literature estimates, our highest estimate $(0.63)$ is almost double that of the highest reported value (0.32).

The genetic correlations between rear udder height, rear udder width and front teat placement with functional herd life found in the current study were generally higher than those reported in the literature. Our estimates ranged from 0.28 to 0.54 , while the corresponding range for literature estimates was -0.07 to 0.21 (Cruickshank et al., 2002; Vukasinovic et al., 2002; Tsuruta et al., 2005). Buenger et al. (2001), Larroque \& Ducrocq (2001), and Schneider et al. (2003) reported that cows with extremely close rear teats were more likely to be culled than cows with extremely wide rear teats.

\section{Conclusion}

Most of the body structure traits had a low to moderate negative genetic correlations with functional herd life in at least one lactation. All udder traits, except for rear teat placement and teat length, showed a significant positive genetic correlation with functional herd life. The following conformation traits were found to be useful indicators of functional herd life: udder depth, fore udder attachment, rear udder height, udder support, rear leg side view, foot angle and dairy strength. The genetic relationships between functional herd life and conformation traits in the South African Jersey breed indicate that conformation traits could be 
used to enhance the accuracy of genetic evaluation for functional herd life. It is therefore recommended that conformation traits should be included in the current national genetic evaluation for functional herd life in the South African Jersey breed.

\section{Acknowledgments}

This study formed part of the first author's doctoral thesis, which benefited from funding from the Agricultural Research Council, South African National Research Foundation and South African Jersey Breed Society. Technical assistance from BE Mostert in preparing data for confirmation traits was greatly appreciated.

\section{References}

Boldman, K.G., Freeman, A.E., Harris, B.L. \& Kuck, A.L., 1992. Prediction of sire transmitting abilities for herd life from transmitting abilities of linear type traits. J. Dairy Sci. 75, 552-563.

Bouška, J., Vacek, M., Štípková, M. \& Němec, A., 2006. The relationship between linear type traits and stayability of Czech Flekvieh cows. Czech J. Anim. Sci. 51, 229-304.

Buenger, A., Ducrocq, V. \& Swalve, H.H., 2001. Analysis of survival in dairy cows with supplementary data on type scores and housing systems from a region of Northwest Germany. J. Dairy Sci. 84, 1531-1541.

Caraviello, D.Z., Weigel, K.A. \& Gianola, D., 2003. Analysis of the relationship between type traits, inbreeding, and functional survival in Jersey cattle using a Weibull proportional hazards model. J. Dairy Sci. 86, 2984-2989.

Cassandro, M., Gallo, L., Carnier, P., Penzo, N. \& Bittante, G., 1999.Collecting functional traits in dairy herds: overview of a program currently running in Italy. In: Proceedings International Workshop on EU Concerted Action on Genetic Improvement of Functional Traits in Cattle (GIFT); Breeding Goals and Selection Schemes 1999. http:www.interbull.slu.se/bulletins/bulletin23/.

Cruickshank, J., Weigel, K.A., Dentine, M.R. \& Kirkpatrik, B.W., 2002. Indirect prediction of herd life in Guernsey cattle. J. Dairy Sci. 85, 1307-1313.

Du Toit, J., Van Wyk, J.B. \& Maiwashe, A., 2009. Genetic parameter estimates for functional herd life for the South African Jersey breed using a multiple trait linear model. S. Afr. J. Anim. Sci. 39, 40-44.

Groeneveld, E., Kovač, M. \& Mielenz, N., 2010. VCE User's Guide and Reference Manual Version 6.0. ftp://ftp.tzv.fal.de/pub/vce6/doc/vce6-manual-3.1-A4.pdf

Jairath, L., Dekkers, J.C.M., Schaeffer, L.R., Liu, Z., Burnside, E.B. \& Kolstad, B., 1998. Genetic evaluation for herd life in Canada. J. Dairy Sci. 81, 550-562.

Larroque, H. \& Ducrocq, V., 2001. Relationships between type and longevity in the Holstein breed. Gent. Sel. Evol. 33, 39-59.

Samoré, A.B., Rizzi, R., Rossoni, A. \& Bagnato, A., 2010. Genetic parameters for functional longevity, type traits, somatic cell scores, milk flow and production in the Italian Brown Swiss. Italian J. Anim. Sci. 9, 145-151.

Schneider, M.D., Dürr, J.W., Cue, R.I. \& Monardes, H.G., 2003. Impact of type traits on functional herd life of Quebec Holsteins assessed by survival analysis. J. Dairy Sci. 86, 4083-4089.

Short, T.H. \& Lawlor, T.J., 1992. Genetic parameters of conformation traits, milk yield and herd life in Holsteins. J. Dairy Sci. 75, 1987-1998.

Strapák, P., Candrák, J. \& Aumann, J., 2005. Selection between longevity and selected production, reproduction and type traits. Czech J. Anim. Sci. 50, 1-6.

Theron, H.E. \& Mostert, B.E., 2004. Genetic analyses for conformation traits in South African Jersey and Holstein cattle. S. Afr. J. Anim .Sci. 34, 47-49.

Tsuruta, S., Misztal, I. \& Lawlor, T.J., 2005. Changing definition of productive life in US Holstein: Effect on genetic correlations. J. Dairy Sci. 88, 1156-1165.

Van Niekerk, D.J., Neser, F.W.C \& Erasmus, G.J., 2000. Genetic parameter estimates for type traits in the South African Jersey breed. S. Afr. J. Anim. Sci. 30, 186-192.

Vollema, A.R. \& Groen, A.B.F., 1997. Genetic correlations between longevity and conformation traits in an upgrading dairy cattle population. J. Dairy Sci. 80, 3006-3014.

Vukasinovic, N., Moll, J. \& Casanova, L., 2001. Implementation of a routine genetic evaluation for longevity based on survival analysis techniques in dairy cattle populations in Switzerland. J. Dairy Sci. 84, 2073-2080. 
Vukasinovic, N., Schleppi, Y. \& Kunzi, N., 2002. Using conformation traits to improve reliability of genetic evaluation for herd life based on survival analysis. J. Dairy Sci. 85, 1556-1562.

Weigel, K.A., Lawlor, T.J., Van Raden, P.M. \& Wiggans, G.R., 1998. Use of linear type and production data to supplement early predicted transmitting abilities for productive life. J. Dairy Sci. 81, 2040-2044.

Zavadilová, L., Němcová, E., Štípková, M. \& Bouška, J., 2009. Relationships between longevity and conformation traits in Czech Fleckvieh cows. Czech J. Anim. Sci. 54 (9), 387-394. 